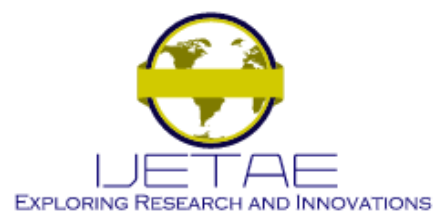

International Journal of Emerging Technology and Advanced Engineering

Website: www.ijetae.com (ISSN 2250-2459, ISO 9001:2008 Certified Journal, Volume 10, Issue 11, November 2020)

\title{
A Novel Way of Addressing Eminent Food Insecurity Challenges Caused by American Fall Army Worms (Spodoptera Frugiperda)
}

\author{
Peter Simon Mamiro ${ }^{1}$, Yudatadei Matei Mosha ${ }^{2}$, Anna Peter Mamiro ${ }^{3}$ \\ ${ }^{1}$ Sokoine University of Agriculture. P. O. Box 3006, Morogoro, Tanzania \\ ${ }^{2}$ Padre Pio Secondary School, P. O. Box 2187, Morogoro, Tanzania \\ ${ }^{3}$ Sokoine University of Agriculture, Graduate P. O. Box 3006 Morogoro, Tanzania
}

\begin{abstract}
American Fall Army Worms Spodoptera frugiperda (J.E. Smith) has been a great nuisance to farmers in West, South, East Africa and Asia imparting significant losses ranging from 80 to $100 \%$ to maize crops while in the fields. This paper presents and describes the results of an investigative study carried out to examine the efficacy of a simple detergent water mixture as an effective remedy for controlling American Fall Army Worms. This should be good news and great relief to governments and farmers at large with regards to time and financial resources that have been used to control these worms. The experiments were carried out at a laboratory in Kilimanjaro street, Kihonda ward, Morogoro region, Tanzania. Various concentrations of 0.1 graduation $(0.1 \%-1.5 \%)$ of detergents (Trade names: KLEESOFT, OMO, FOMA, ARIEL and FAMILY) water mixtures were prepared. These were applied to the worms to detect; which concentration was effective in killing them in the shortest time possible. Five worms were subjected to each concentration of detergent:water mixture and the time was recorded to detect the duration it took to kill the worms. Simple detergent:water mixtures have shown to be very effective in controlling the American Fall Army Worms. For each concentration prepared from $0.1 \%$ to $1.5 \%$ we observed a $100 \%$ mortality of the worms, with only difference being the time to kill. On average at $0.1 \%$, the worms were killed in 689 seconds $(\approx 12$ minutes), while at $1.5 \%$, the worms were killed in 32 seconds $(\approx 0.5$ minutes). The duration decreased with level of concentration of the detergent. As the detergent concentration increased less and less time was required to kill the worms completely. From the lowest concentration $0.1 \%$ to the highest $1.5 \%$, there was a $100 \%$ mortality of the worms, with the only difference being time to kill. A $0.5 \%$ detergent:water mixture has been shown to be very effective in killing the fall army worms within 60 seconds as the difference in time to kill was negligible after this concentration. The findings of this study call for urgent need to introduce this remedy to all farmers in order to protect maize and other crops in the fields during production season and to reduce financial burden incurred by farmers in purchasing costly pesticides.
\end{abstract}

Further research is needed to explore the specific content of the detergents that causes abrupt death and the mechanism in which the worms are killed.

Keywords - American Fall Army Worms, Cost-effective, Detergents, Farmers, Maize, Pesticides

\section{INTRODUCTION}

American Fall armyworm (AFAW), Spodoptera frugiperda (J.E. Smith) is a polyphagous destructive pest that attacks economically important crops such as maize, wheat, millet, sorghum, sugarcane and rice at all stages, in which the damage can lead to 100 percent crop loss [22,5]. The AFAW develop through six developmental instars, with the last instar causing over $70 \%$ of the overall damage [1]. The larval stage is about 14 days [14]. A single larva can consume about $140 \mathrm{~cm}^{2}$ of maize leaf area to complete the larval development period [1]. AFAW is capable of feeding on over 80 different crop species, making it one of the most damaging crop pests [37]. The pest belongs to Kingdom: Animalia, Order: Lepidoptera, Family: Noctuidae, Genus: Spodoptera and Species: Spodoptera frugiperda [12]. The larval stages $1^{\text {st }}$ to $5^{\text {th }}$ instars are considered the stages that cause heavy crop losses. Among the crops mentioned above, maize is the most important staple cereal crop grown by smallholder farmers in SubSaharan Africa and is one of the dominant cereals grown in most other African countries [12, 36]. The larvae feed voraciously on the maize plant leaves by staying in between the nodal and pedicel region of the leaves [3]. They feed by scraping the leaf surface as they loosen causing defoliation [7].

AFAW, is native to tropical and sub-tropical region of America that has spread worldwide uncontrollably to Africa and Asia [6]. AFAW appeared for the first time in 2016 on maize crops in Central and West Africa, Nigeria in particular $[23,9,34)$. 


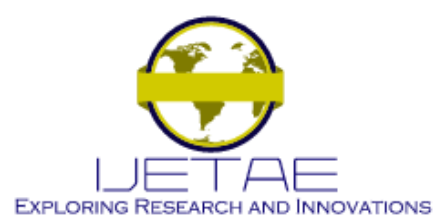

International Journal of Emerging Technology and Advanced Engineering Website: www.ijetae.com (ISSN 2250-2459, ISO 9001:2008 Certified Journal, Volume 10, Issue 11, November 2020)

By 2017 the pest spread very quickly, as it was found in most of sub-Saharan Africa [12], threatening food security in individual countries [15]. Due to its rapid spread and distinctive ability to inflict widespread damage across multiple crops, AFAW poses a serious threat to the food and nutrition security and livelihoods of hundreds of millions of farming households in Sub Saharan Africa [37]. According to Huesing [33], some of the factors that helped AFAW to spread quickly over the continent were their propensity to attack a wide range of crops and their ability to migrate over long distances [39]. Equally, adult AFAW moths are strong flyers [38], which have enabled the pests to spread very fast in Africa in 2016, India 2018 [35], Myanmar [20], and China [19]. This pest has caused unsurmountable financial losses in African countries with respect to loss in planted and harvested maize crop [12, 40].

Several approaches that have been reported to control AFAW include; cultural, biological and chemical control [24, 18, 12]. Of all the mentioned approaches the control of AFAW has usually been achieved through the application of synthetic insecticides [4]. However, it has been reported that these methods were costly, causes environmental pollution, at most times the worms developed resistance to chemicals and often pest resurgence [10, 11]. Some pesticides that are currently applied to control AFAW include pyrethroids, carbamates and organophosphates [1]. The aim of this paper is to inform the General Public that a simple and effective remedy of the devastating AFAW pest has been found. Secondly, the remedy is very affordable to poor farmers

\section{MATERIALS AND METHODS}

\section{A. Materials}

Table 1 shows the materials that were used in the experiments. The experiments were carried out at a laboratory in Kilimanjaro street, Kihonda ward, Morogoro region, Tanzania.
TABLE 1

MATERIAL REQUIREMENT

\begin{tabular}{|l|l|c|}
\hline S/No. & \multicolumn{1}{|c|}{ Materials } & Amount \\
\hline 1. & $\begin{array}{l}\text { Laboratory weighing scale (ACPro-200 } \\
\text { 200g x 0.01g Lot No03-20588) }\end{array}$ & 1 \\
\hline 2. & $\begin{array}{l}\text { Detergents (KLEESOFT, OMO, } \\
\text { FOMA, ARIEL, FAMILY): Each 50 } \\
\text { grams pack }\end{array}$ & 4 \\
\hline 3. & Beakers 100 mL capacity & 75 \\
\hline 4. & ${\text { Worms: } 5^{\text {th }} \text { or } 6^{\text {th }} \text { Instars growth stage }}^{\text {Petri dishes: with a capacity of } 100 \mathrm{~mL}}$ & 375 \\
\hline 5. & Measuring cylinder: $100 \mathrm{~mL}$ & 75 \\
\hline 6. & Stop watch & 1 \\
\hline 7. & Distilled water (Litres) & 5 \\
\hline 8. &
\end{tabular}

\section{B. Methods}

\section{Collection of American Fall Army Worms:}

A total of 375 live worms that were approximately in their $5^{\text {th }}$ to $6^{\text {th }}$ instars growth stage, were collected from maize fields in Kilimanjaro street, Kihonda ward, Morogoro, Tanzania. These worms were put in a wellventilated plastic container, ready for the experiment. An instar refers to the developmental stage of an arthropod between moults [1]. For instance, after hatching from the egg the larvae or worm is referred to the first instar. When the larvae/worm moults again become a second instar and so on. The AFAW larvae/worm develop through six developmental instars and the sixth is the complete mature worm [14].

\section{Preparation of Detergent:Water Mixtures:}

The following concentrations of Detergent/Distilled water mixtures were prepared: $0.1 \%, 0.2 \%, 0.3 \%, 0.4 \%$, $0.5 \%, 0.6 \%, 0.7 \%, 0.8 \%, 0.9 \%, 1.0 \%, 1.1 \%, 1.2 \%, 1.3 \%$, $1.4 \%$ and $1.5 \%$ as shown in Table 2 . The Table indicates the amount of detergent measured in grams for each concentration. A laboratory weighing scale (ACPro-200 200gx0.01g Lot No03-20588) was used to weigh the detergent for each mixture. The weighed detergents were put in a total of 15 beakers. A measuring cylinder was used to measure and dispense $50 \mathrm{~mL}$ of distilled water for each concentration into the beakers containing the detergents and mixed well until the detergents were clearly mixed. 


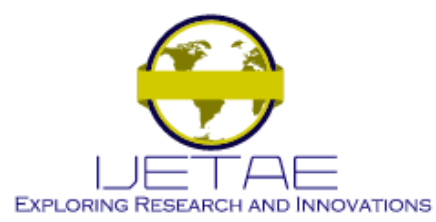

International Journal of Emerging Technology and Advanced Engineering Website: www.ijetae.com (ISSN 2250-2459, ISO 9001:2008 Certified Journal, Volume 10, Issue 11, November 2020)

TABLE 2:

CONCENTRATION OF DETERGENT: DISTILLED WATER MIXTURE

\begin{tabular}{|c|c|c|c|c|}
\hline Sample No. & Detergent (grams) & $\begin{array}{c}\text { Distilled Water } \\
(\mathrm{mL})\end{array}$ & $\begin{array}{c}\text { Detergent Concentration } \\
(\mathrm{g} / \mathrm{mL})\end{array}$ & $\begin{array}{c}\text { Detergent } \\
\text { Concentration }(\%)\end{array}$ \\
\hline 1 & 0.05 & 50 & 0.001 & 0.1 \\
\hline 2 & 0.10 & 50 & 0.002 & 0.2 \\
\hline 3 & 0.15 & 50 & 0.003 & 0.3 \\
\hline 4 & 0.20 & 50 & 0.004 & 0.4 \\
\hline 5 & 0.25 & 50 & 0.005 & 0.5 \\
\hline 6 & 0.30 & 50 & 0.006 & 0.6 \\
\hline 7 & 0.35 & 50 & 0.007 & 0.7 \\
\hline 8 & 0.40 & 50 & 0.008 & 0.8 \\
\hline 9 & 0.45 & 50 & 0.009 & 0.9 \\
\hline 10 & 0.50 & 50 & 0.010 & 1.0 \\
\hline 11 & 0.55 & 50 & 0.011 & 1.1 \\
\hline 12 & 0.60 & 50 & 0.012 & 1.2 \\
\hline 13 & 0.65 & 50 & 0.013 & 1.3 \\
\hline 14 & 0.70 & 50 & 0.014 & 1.4 \\
\hline 15 & 0.75 & 50 & 0.015 & 1.5 \\
\hline
\end{tabular}

3. Mode of Exposing the Worms to the Detergents:

For each detergent, 15 petri-dishes were arranged in a single row and labelled in order of increasing concentration $(0.1 \%$ to $1.5 \%)$. About $30 \mathrm{~mL}$ of each concentration was poured into the petri-dishes from the beakers. Five (5) AFAW in their $5^{\text {th }}$ or $6^{\text {th }}$ in-stars growth stage were put on each petri-dish at a time and a stopwatch was started. The stopwatch was stopped when the fifth worm was killed. The time was recorded in seconds.

\section{Response of the Efficacy of the Detergent:Water Mixtures from the General Public:}

When we discovered this mixture to be effective against AFAW, in March, 2020 during maize production season in Tanzania, we sent a video clip in the internet in order to inform various stakeholders including the farmers on this discovery so that they could use in their farms to save their maize crop. After one week, we started to get feedback from users of the detergent:water mixtures on how effective the detergent mixture was in controlling AFAW. We then called by phone 10 participants (6 males, 4 females) who used the detergent:water mixtures and asked them structured questions, which compared the experience of using the chemical pesticides and detergent:water mixtures. The respondents retorted by comparing the detergents and the chemical pesticides they have been applying on several aspects such as, cost/litre or kilogram, cost of spraying per acre, odour/smell, effect to the environment, efficacy, spray concentration and time the worms were killed after application.

\section{Data Analysis}

Data analysis was performed using Statistical Product and Service Solutions (SPSS) version 25. Descriptive statistics was used to explore distribution of the time to kill the AFAW and concentration of the detergents. The results were presented both in a tabular format and the scatter diagram. The tabular format was used in presenting the various concentrations employed and the time taken for the worms to be killed by the detergents. The scatter diagrams were used to show the time trend on how AFAW were killed with detergents concentrations.

\section{RESULTS}

\section{E.Time Taken to Kill the Worms: Lethal Dose Determination}

Based on the concentrations prepared, the time in seconds the last worm of the five worms was killed for each concentration was recorded as indicated in Table 3. The time the worms were killed was inversely proportional to the concentration of the detergents; that is; as the concentration of the detergents increased, the time taken to kill the worms decreased. However, for each detergent concentration prepared from $0.1 \%$ to $1.5 \%$, we observed a $100 \%$ mortality of the worms, with only difference being the time they were killed. On average at $0.1 \%$, the worms were killed in 689 seconds $(\approx 12$ minutes), while at $1.5 \%$, the worms were killed in 32 seconds $(\approx 0.5$ minutes $)$. 


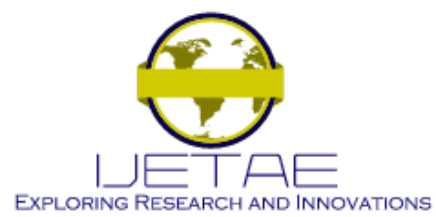

International Journal of Emerging Technology and Advanced Engineering Website: www.ijetae.com (ISSN 2250-2459, ISO 9001:2008 Certified Journal, Volume 10, Issue 11, November 2020)

TABLE 3:

CONCENTRATION OF DETERGENT/DISTILLED WATER MIXTURES PREPARED AND TIME TO KILL

\begin{tabular}{|c|c|c|c|c|c|c|c|c|}
\hline \multirow[t]{2}{*}{ S/No. } & \multirow{2}{*}{$\begin{array}{c}\text { Detergent } \\
\text { Concentration } \\
(\%)\end{array}$} & \multirow{2}{*}{$\begin{array}{c}\text { Number of } \\
\text { Worms' at } 5^{\text {th }} \\
\text { or } 6^{\text {th }} \text { Instars } \\
\text { Growth Stage }\end{array}$} & \multicolumn{6}{|c|}{ Time the worms were killed (seconds) } \\
\hline & & & KLEESOFT & OMO & ARIEL & FOMA & FAMILY & $\begin{array}{l}\text { Mean of al } \\
\text { Detergents }\end{array}$ \\
\hline (1) & 0.1 & 5 & 676 & 702 & 653 & 723 & 692 & 689.2 \\
\hline$(2)$ & 0.2 & 5 & 410 & 398 & 450 & 463 & 557 & 455.6 \\
\hline (4) & 0.4 & 5 & 120 & 97 & 92 & 139 & 91 & 107.8 \\
\hline (5) & 0.5 & 5 & 58 & 48 & 61 & 56 & 54 & 55.4 \\
\hline (6) & 0.6 & 5 & 57 & 46 & 55 & 53 & 51 & 52.4 \\
\hline (7) & 0.7 & 5 & 53 & 43 & 53 & 51 & 47 & 49.4 \\
\hline (11) & 1.1 & 5 & 47 & 32 & 41 & 37 & 38 & 39.0 \\
\hline$(12)$ & 1.2 & 5 & 45 & 30 & 39 & 36 & 35 & 37.0 \\
\hline (13) & 1.3 & 5 & 43 & 29 & 35 & 33 & 33 & 34.6 \\
\hline (14) & 1.4 & 5 & 43 & 27 & 32 & 31 & 30 & 32.6 \\
\hline$(15)$ & 1.5 & 5 & 43 & 26 & 30 & 31 & 29 & 31.8 \\
\hline
\end{tabular}

Figure 1, 2, 3, 4 and 5 displays the linear, quadratic and cubic trends of time taken to kill the worms by concentration of KLEESOFT, OMO, FOMA, ARIEL and FAMILY detergents, respectively. Figure 6 shows the average trend of all detergents. All the detergents showed a similar pattern in killing the worms with increase in concentration. The results showed that the cubic trend lines were a better fit for the data than the linear and quadratic trend lines.
With cubic trend lines, it was noted that the time to kill decreased with increasing concentration of the detergents:water mixtures. However, after the detergents' reached a concentration of $0.5 \mathrm{~g} / 100 \mathrm{~mL}(0.5 \%)$, the difference in time to kill was negligible. This indicated that the optimal value of detergent concentration to be used was $0.5 \mathrm{gm} / 100 \mathrm{~mL}(0.5 \%)$. Otherwise by increasing the concentration of detergent:water mixtures, the time to kill was negligible and hence there is no need of adding more detergent as it will increase cost with no tangible savings of the detergents. 


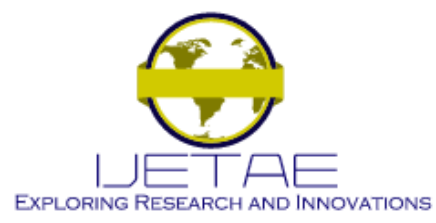

International Journal of Emerging Technology and Advanced Engineering

Website: www.ijetae.com (ISSN 2250-2459, ISO 9001:2008 Certified Journal, Volume 10, Issue 11, November 2020)

KLEESOFT DETERGENT

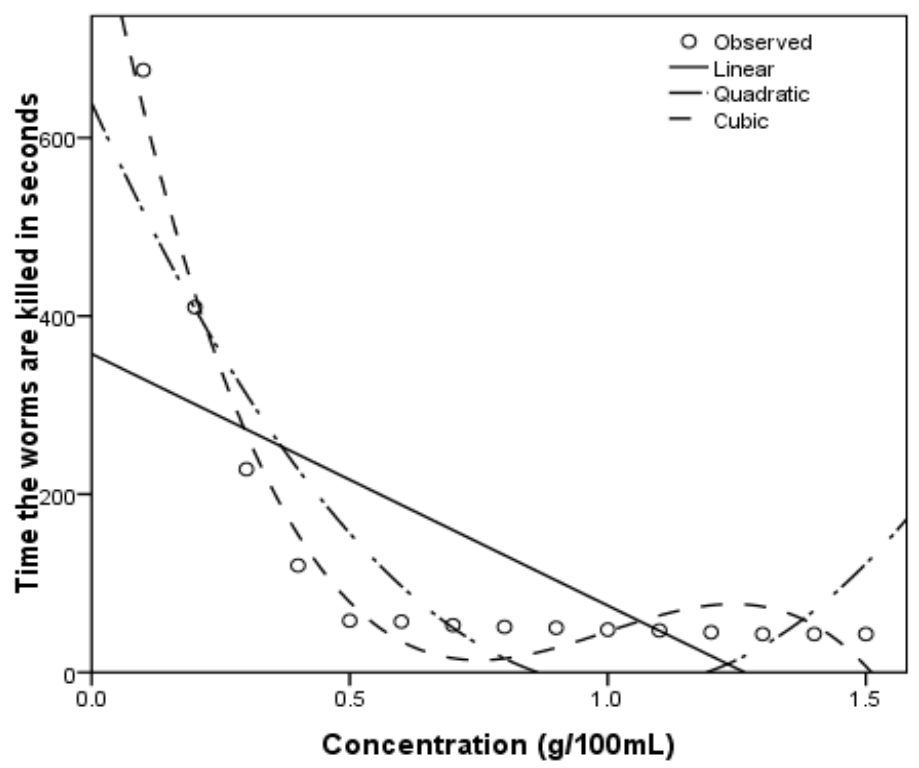

Figure 1: The distribution of observed and predicted values of time to kill in seconds by concentration of the KLEESOFT detergent for three different models

OMO DETERGENT

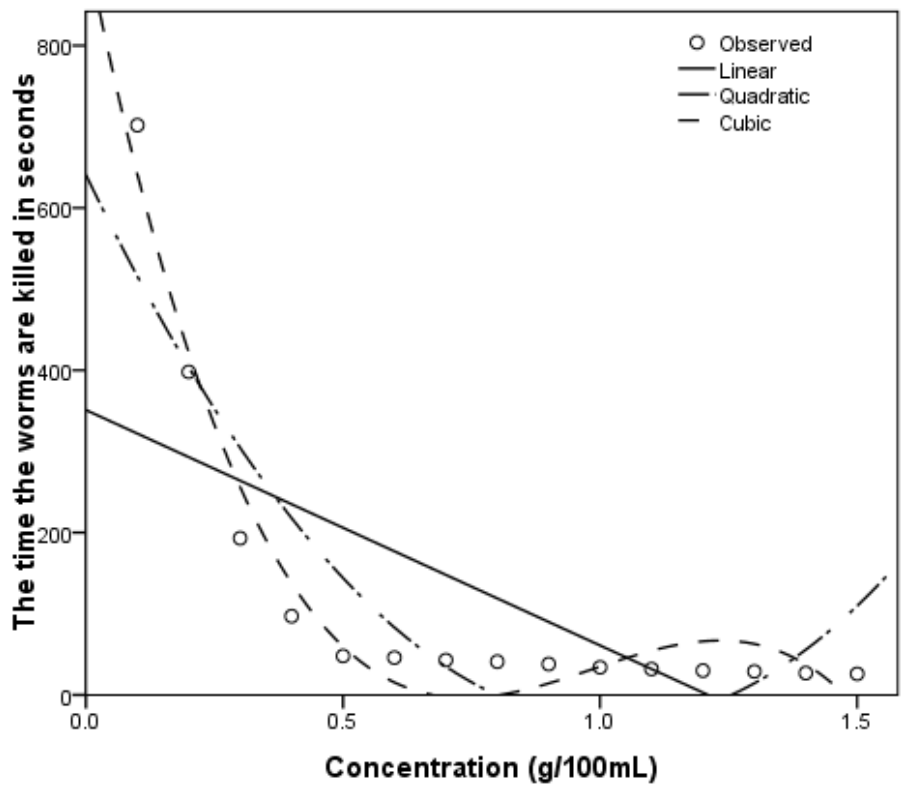

Figure 2: The distribution of observed and predicted values of time to kill in seconds by concentration of the OMO detergent for three different models. 


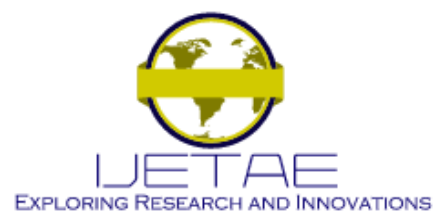

International Journal of Emerging Technology and Advanced Engineering

Website: www.ijetae.com (ISSN 2250-2459, ISO 9001:2008 Certified Journal, Volume 10, Issue 11, November 2020)

FOMA DETERGENT

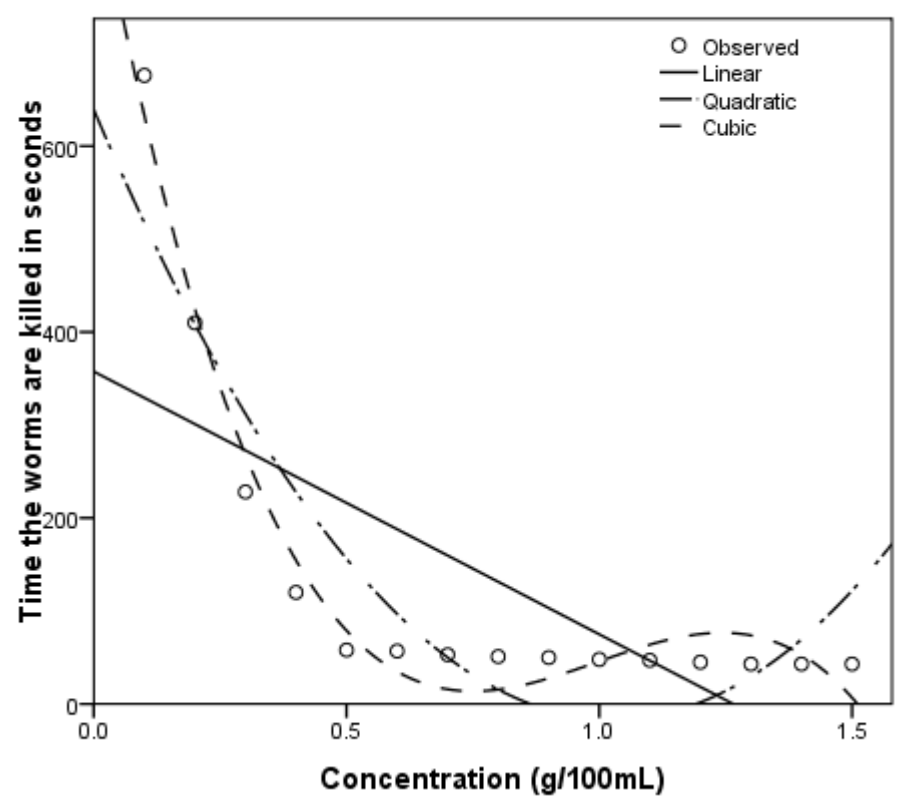

Figure 3: The distribution of observed and predicted values of time to kill in seconds by concentration of the FOMA detergent for three different models.

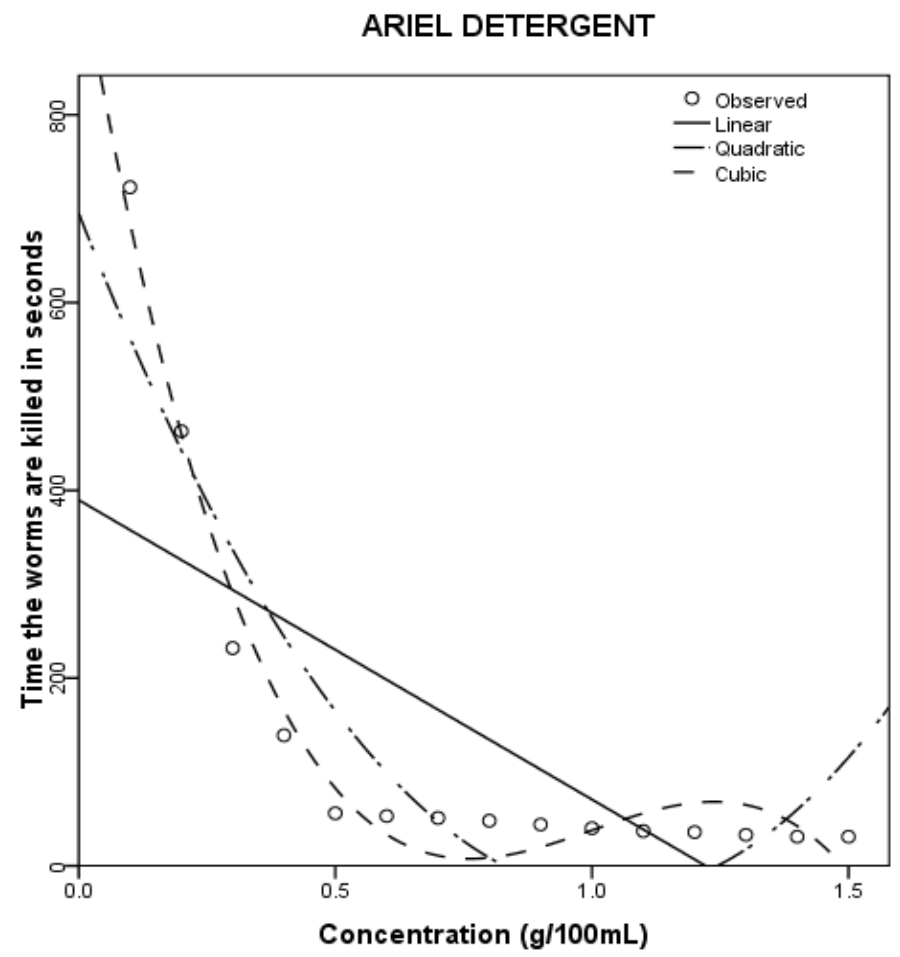

Figure 4: The distribution of observed and predicted values of time to kill in seconds by concentration of the ARIEL detergent for three different models. 


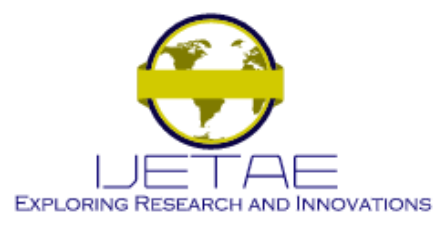

International Journal of Emerging Technology and Advanced Engineering

Website: www.ijetae.com (ISSN 2250-2459, ISO 9001:2008 Certified Journal, Volume 10, Issue 11, November 2020)

FAMILY DETERGENT

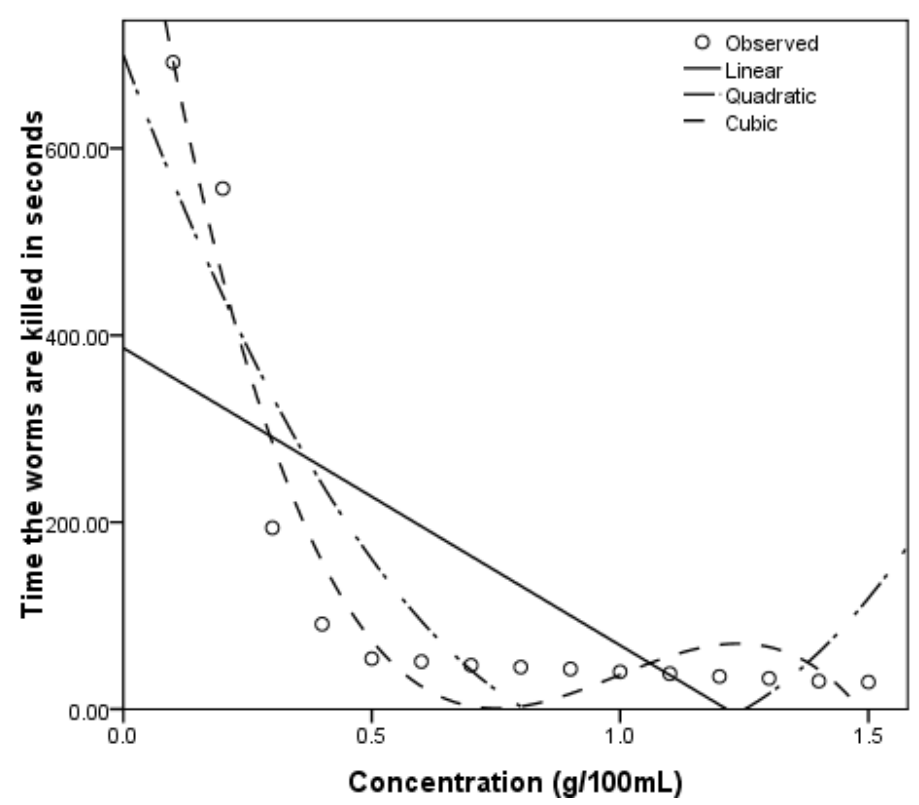

Figure 5: The distribution of observed and predicted values of time to kill in seconds by concentration of the FAMILY detergent for three different models.

MEAN OF ALL DETERGENTS

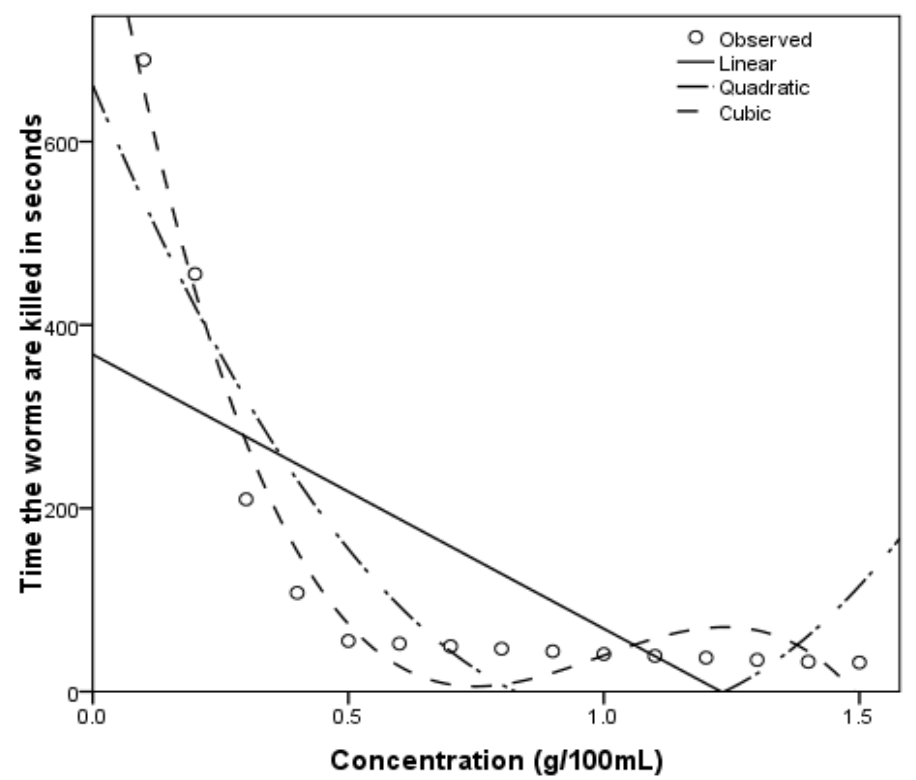

Figure 6: The distribution of observed and predicted values of time to kill in seconds by concentration of the Mean of all detergents for three different models 


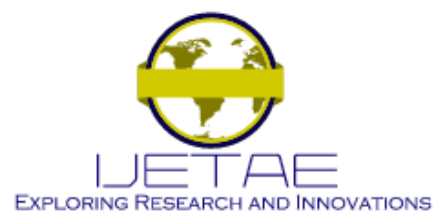

International Journal of Emerging Technology and Advanced Engineering Website: www.ijetae.com (ISSN 2250-2459, ISO 9001:2008 Certified Journal, Volume 10, Issue 11, November 2020)

\section{F. Feedback of the Efficacy of the Detergent:Water Mixtures from the General Public}

The responses to the questions of those who sprayed the detergent:water mixtures to control AFAW are summarized in Table 4 . The respondents retorted by personal evaluation of using the detergent:water mixtures with the experience they had, in using the chemical pesticides. The price per litre for the chemical pesticides ranged from US\$ 10 to US\$ 21, Tanzanian Shillings Equivalent, while the detergents were purchased on average of US\$ 3 per kilogram. The cost for spraying an acre for the chemical pesticides ranged from US\$ 5 to US\$10.5, while for the detergents costed US\$ 0.9 only.
All respondents generally agreed that the cost of using the detergents was very low and could be afforded by most farmers. Responding to the efficacy of the detergent:water mixtures in controlling the AFAW, they reported as; very effective and death was certain, and within a very short time of less than 3 minutes on average. Reporting on the smell of detergents while spraying, all the respondents said they enjoyed as the smell was good and perfumed contrary to the choking chemical pesticides. They all agreed that as a result of using the detergent:water mixtures, pollution to the environment might be very minimal as the concentration of the detergents used was relatively low $(0.5 \%)$.

TABLE 4:

COMPARISON OF THE DETERGENT MIXTURE AND THE CHEMICAL PESTICIDES

\begin{tabular}{|c|c|c|c|}
\hline S/No. & Criterion & Chemical pesticide & Detergents water mixtures \\
\hline (1) & \multirow{5}{*}{$\begin{array}{l}\text { Cost: Price per } \\
\text { Litre/kilogram }\end{array}$} & $\begin{array}{l}\text { Vitashield } 48 \text { EC ( } 48 \% \text { chlorpyrifos ethyl): Equivalent to } \\
\text { US\$ } 16 \text { per litre }\end{array}$ & \multirow{5}{*}{$\begin{array}{l}\text { Detergents: KLEESOFT, OMO, } \\
\text { ARIEL, FOMA AND FAMILY. } \\
\text { Equivalent to US\$ } 3 \text { per } \\
\text { kilogram }\end{array}$} \\
\hline$(2)$ & & $\begin{array}{l}\text { Select-Plus } 315 \text { EC (Profenofos+lambdacyhalothrin) } \\
\text { Equivalent US\$ } 10 \text { per litre }\end{array}$ & \\
\hline (3) & & $\begin{array}{l}\text { Bamethrin 5EC (Deltamethrin 5g/L) Equivalent US\$ } 21 \\
\text { per litre }\end{array}$ & \\
\hline (4) & & $\begin{array}{l}\text { Kung-Fu } 5 \text { EC (Lambda-cyhalothrin) Equivalent to US\$ } \\
18 \text { per litre }\end{array}$ & \\
\hline$(5)$ & & $\begin{array}{l}\text { Duduba } 450 \text { EC (Cypermethrin 10\%+chlorpyrifos 35\%) } \\
\text { Equivalent to US\$ } 18 \text { per litre }\end{array}$ & \\
\hline$(6)$ & Efficacy & $\begin{array}{l}\text { Not very effective and at times does not kill. Sometimes } \\
\text { advised to use mixture of two or three insecticides at one } \\
\text { time }\end{array}$ & Very effective, kills $100 \%$ \\
\hline (7) & $\begin{array}{l}\text { Liters enough to spray an } \\
\text { acre }\end{array}$ & 80 litres: Chemical:Water mixture & $\begin{array}{l}80 \text { litres: Detergent:Water } \\
\text { mixture }\end{array}$ \\
\hline$(8)$ & \multirow{6}{*}{ Cost of spraying an acre } & Vitashield $40 \mathrm{EC}$ ( $40 \%$ chlorpyrifos ethyl): $500 \mathrm{~mL}$ per & \multirow{6}{*}{$\begin{array}{l}\text { Detergent:water mixture: } \\
\text { Equivalent to US\$ } 0.9 \text { per acre }\end{array}$} \\
\hline (9) & & acre; Equivalent US\$ 8 per $1 / 2$ litre & \\
\hline$(10)$ & & $\begin{array}{l}\text { Select-Plus } 315 \mathrm{EC}, 500 \mathrm{~mL} \text { per acre; Equivalent to US\$ } \\
5 \text { per } 1 / 2 \text { litre }\end{array}$ & \\
\hline$(11)$ & & $\begin{array}{l}\text { Bamethrin } 2.5 \mathrm{EC}, 500 \mathrm{~mL} \text { per acre; Equivalent to US\$ } \\
10.5 \text { per } 1 / 2 \text { litre }\end{array}$ & \\
\hline$(12)$ & & $\begin{array}{l}\text { Kung-Fu (Lambda-cyhalothrin), } 300 \mathrm{~mL} \text { per acre; } \\
\text { Equivalent US\$ } 9 \text { per } 300 \mathrm{~mL}\end{array}$ & \\
\hline$(13)$ & & $\begin{array}{l}\text { Duduba } 450 \text { EC (Cypermethrin } 10 \%+\text { chlorpyrifos } 35 \%) \\
\text { US\$ } 9 \text { per } 1 / 2 \text { litre }\end{array}$ & \\
\hline$(14)$ & Overall cost & Relatively high & Relatively very low \\
\hline$(15)$ & Smell while spraying & Choking after mixing with water & Good and perfumed \\
\hline (16) & Environmental pollution & Relatively bad and high & Relatively very little \\
\hline$(17)$ & Spraying on plant & Spray economically due to high cost of the chemical & $\begin{array}{l}\text { Spray to the whole plant since its } \\
\text { affordable }\end{array}$ \\
\hline$(18)$ & Duration of worm death & 1-2 days on average, sometimes do not kill & Less than 3 minutes on average \\
\hline
\end{tabular}




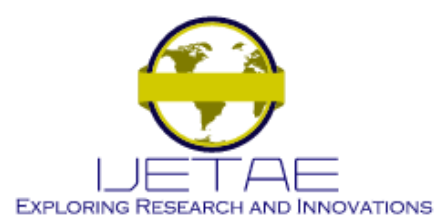

\section{International Journal of Emerging Technology and Advanced Engineering Website: www.ijetae.com (ISSN 2250-2459, ISO 9001:2008 Certified Journal, Volume 10, Issue 11, November 2020)}

\section{DISCUSSION}

AFAW has been a great nuisance to farmers in West, South and East Africa imparting 80 to $100 \%$ loss to maize crops while in the fields $[21,37,22]$. However, the results of these detergent:water mixtures show that the AFAW are very susceptible to even very low concentration of $0.001 \mathrm{~g} / \mathrm{mL}(0.1 \%)$ of detergents. According to GAIN [22], AFAW were detected for the first time in Ruvuma and Mbeya regions located in southern Tanzania in February 2017. Interventions to control AFAW by the Government of Tanzania (GoT) were initiated by the Permanent Secretary in the Ministry of Agriculture, Livestock and Fisheries, in April 2017. The GoT embarked on various initiatives to control the situation in Katavi, Mbeya and Songwe regions. The GoT deployed agricultural experts, bought and distributed pesticides worth $\$ 132,439$, and trained farmers on how to fight the worms. With this intervention by the government it was possible to control the invasion by 70 percent. During this period nearly 30 percent of the country was already affected and most farmers complained of incurring huge costs to contain the worms. The Food and Agriculture Organization of the United Nations (FAO) and the Ministry of Agriculture signed a cooperation agreement on 31/01/2018, that aimed to support Tanzania in building its surveillance and management capacity to respond efficiently to AFAW invasion in the country [17].

An informative video on the control of AFAW in maize provided information about the initial attack of AFAW in Africa, and subsequent attacks in various regions of Tanzania (https://www.sua.ac.tz/news/fall-armywormfarmers-nightmare [27]. Another video showed the spread and initial attacks of AFAW in Africa, and subsequent in various states of India. (https://video.search.yahoo.com/search/video?p=fall+army worm+control+in+india+youtube\#id=1\&vid=db22db61e8b a3eba912a46e486262567\&action=click_[26]. The video informed that AFAW had become a major threat and, hence its timely control was imperative. Another video prepared by FAO, explained the 'Best Practices for AFAW Management' in Africa https://www.youtube.com/watch?v=JlFOZAj3iT8. [29]

In Uganda scientist have been trying hard to control AFAW

(https://www.youtube.com/watch?v=p05C1q2HRrg__ [31], however advices by agricultural experts have been on the use of insecticides. In the same country, AFAW outbreaks continued spreading and reached 78 districts by May 2017 and later to other districts in North Eastern part of the country [22].
The Government of Uganda (GoU) distributed pesticides to affected farmers. The pest was reported causing a total crop loss in some places where replanting was necessitated. The GoU developed an action plan with a budget of USD 1 million but they had estimated a potential annual loss of some 450,000 MT of maize to established and unabated AFAW outbreaks. Malawi farmers went an extra mile to try other materials like detergents and salt mixture (https://www.youtube.com/watch?v=9tOLYD7eJEA_ [28]. However, the detergent mixed with salt was just applied in solid form without a known concentration. In this study known concentrations have been tested and optimal concentration have been determined.

Zambia had its own efforts to control the pest by using FORTENZA ${ }^{\text {TM} D u o ~(C y a n t r a n i l i p r o l e+T h i a m e t h o x a m) ~}$ insecticide seed treatment to control the pest (https://www.youtube.com/watch?v=ZCFuI2ja8Oo__ [32]. Maize growers informed that it was quite effective although no mention was given on the cost of the insecticide. A video clip titled 'Fall armyworm wreaks havoc in southern Africa' (https://www.youtube.com/watch?v=jR4p_AWuFZc [30] is another evidence how this worm has been a threat to countries in the southern block of Africa. Up to early June 2017, in Kenya, the pest had been reported in 27 of the 47 counties threatening more than 200,000 hacters of maize crop. Ground control operations continued in all affected areas by farmers with assistance and coordination from the Ministry of Agriculture [22]. However, in a survey conducted by De-Groote et al. [13] in Kenya, on pesticides control of AFAW, about $60 \%$ of the farmers interviewed perceived pesticides as not effective in controlling AFAW.

Scientists in India came up with simple organic methods for controlling the worms like applying individually soil, rock dust, charcoal powder, or wood-ash into the maize whorls with some success. The most effective method was application of soil/soil slurry in the maize whorls in which the worms were killed after three to four days (https://video.search.yahoo.com/search/video?p=fall+army +worm+control+in+india+you+tube+using+sand+and+ash \#id=1\&vid=6518d41210a41875581260134cec60e1\&action $=$ click [25]. According to Fotso et al. [21], other efforts for the control of AFAW have focused on identifying potential indigenous natural enemies and screening soft insecticides and biopesticide as part of an integrated control of the pest.

On the $7^{\text {th }}$ January 2019, The Citizen Newspaper carried a title 'The Tropical Pesticides Research Institute (TPRI) issues new guidelines to control fall armyworms- Arusha'. The story narrated that, TPRI has released a new system of controlling AFAW. 


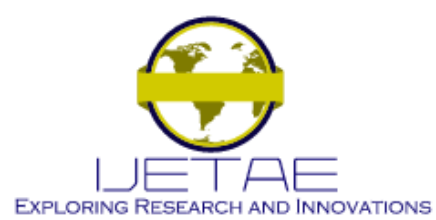

\section{International Journal of Emerging Technology and Advanced Engineering Website: www.ijetae.com (ISSN 2250-2459, ISO 9001:2008 Certified Journal, Volume 10, Issue 11, November 2020)}

The move came after seven pesticides, developed by TPRI in 2017, proved to be ineffective against the type of worms, scientifically known as Spodoptera frugiperda. The pesticides included Belt 480 SC, Duduba $450 \mathrm{EC}$, and Emamectin Benzoate, Mupacron 50EC, Abamectin 5\% and Lambda Cyhalothrin 'karate' [8].

Several approaches by FAO and individual countries have been made to eradicate the AFAW but it has all been in vain. Huge resources have been used in form (i) Purchasing and applying pesticides of different kinds (ii) Holding conferences, webinar and seminars and workshops for exchanging experiences on the control of AFAW and (iii) Publications that came from international organizations working in the field, including the Food and Agriculture Organization $[16,18]$ and the International Maize and Wheat Improvement Centre (CIMMYT) [37].

\section{CONCLUSIONS}

For each concentration we observed a $100 \%$ mortality of the AFAW regardless of time. However, the detergent:water mixture of a concentration of $0.5 \%$ seems to be very effective in destroying the worms in about 60 seconds as the difference in time to kill was negligible after this concentration. The mixture is cost effective as most farmers could purchase these detergents and apply to their maize in the fields. Governments will do away with expensive chemical controls that cost governments huge financial resources that can be allocated to other important requirements.

\section{RECOMMENDATIONS}

The findings of this study call for urgent need to introduce this remedy to all farmers in order to protect maize and other crops in the fields during production season as the worms are extremely susceptible to the detergent:water mixtures and hence reduce financial burdens incurred by farmers in purchasing costly pesticides. The authors would like to urge Ministries of Agriculture in all countries facing AFAW problem to use this protocol in order to improve food and nutrition security by ensuring bumper harvests in their respective countries. Nevertheless, further research is needed to: (i) explore the specific content of the detergents that causes sudden or abrupt death of the worms and (ii) determine the mechanism in which the detergents kill the worms.

\section{ACKNOWLEDGMENTS}

The authors would like to thank Prof. Joyce Kinabo and Dr. Nyamizi Bundala from Sokoine University of Agriculture for their careful, constructive and insightful comments during reviewing this work. The authors are also very grateful to Dr. Abdallah Hussein from University of Dodoma for assisting in data analysis;

\section{DECLARATION OF CONFLICT OF INTERESTS}

The authors declare that, they do not have conflicts of interest with respect to the research, authorship, and/or publication of this article. In addition, the authors do not have any commercial or other association that might pose a conflict of interest.

\section{FUNDING}

The funding for this research was self-sponsored by the authors.

\section{REFERENCES}

[1] Assefa, F. and Ayalew, D., 2019. Status and control measures of fall armyworm (Spodoptera frugiperda) infestations in maize fields in Ethiopia: A review: Moral, M. T (Reviewing editor), Cogent Food \& Agriculture, 5:1, DOI: 10.1080/23311932.2019.1641902.

[2] Bate, T., van Huis, A. and Ampofo, J. K. 2000. Pest management strategies in traditional agriculture: an African perspective. Annual Review of Entomology 45:631-59

[3] Blanco, C. A., Chiaravalle, W., Dalla-Rizza, M., Farias, J. R., García-Degano, M. F., Gastaminza, G. Pieralisi, B. K., MotaSánchez, D., Murúa, M. G., Omoto, C., Rodríguez-Maciel, J. C., Terán-Santofimio, H., Terán-Vargas, A. P., Valencia, S. J. and Willink, E. 2016. Current situation of pests targeted by Bt crops in Latin America. Current Opinion in Insect Science, 15, 131-138. doi:10.1016/j.cois.2016.04.012.

[4] Blanco, C. A., Pellegaud, J. G., Nava-Camberos, U., Lugo-Barrera, D., Vega-Aquino, P., Coello, J., Terán Antonio, T. and VargasCamplis, J. 2014. Maize pests in Mexico and challenges for the adoption of integrated pest management programs. Journal of Integrated Pest Management, 5(4), E1-E9. doi:10.1603/IPM14006.

[5] CABI 2017. Spodoptera frugiperda (fall army worm) invasive species compendium. Retrieved from http://www.cabi.org/isc/datasheet/29810.

[6] Chhetri's, L. B. and Acharya, B. 2019. Fall armyworm (Spodoptera frugiperda) : A threat to food security for south Asian country : Control and management options : A review. Farming. \& Management. 4 (1) : 38-44 DOI: 10.31830/2456-8724.2019.004.

[7] Chimweta, M., Nyakudya, I. W., Jimu, L. and Mashingaidze, A. B. (2020) Fall armyworm [Spodoptera frugiperda (J.E. Smith)] damage in maize: management options for flood-recession cropping smallholder farmers, International Journal of Pest Management, 66:2, 142-154, DOI: 10.1080/09670874.2019.1577514. 


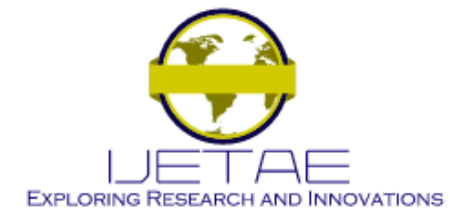

\section{International Journal of Emerging Technology and Advanced Engineering Website: www.ijetae.com (ISSN 2250-2459, ISO 9001:2008 Certified Journal, Volume 10, Issue 11, November 2020)}

[8] CITIZEN (7th January 2019) Tanzania: TPRI Issues New Guidelines to Control Fall Armyworms. The citizen Newspaper, Reported by Bertha Ismail; Bertha Ismail @TheCitizenTZ news@tz.nationmedia.com

[9] Cock, M. J. W., Beseh P. K., Buddie A. G., Cafá, G. and Crozier J. (2017) Molecular methods to detect Spodoptera frugiperda in Ghana, and implications for monitoring the spread of invasive species in developing countries. Sci. Rep. 7:4103. doi: 10.1038/s41598-01704238-y.

[10] Colborn, T. (1995). Pesticides-How research has succeeded and failed to translate science into policy: Endocrinological effects on wildlife. Environmental Health Perspectives, 103(Suppl 6), 81.

[11] Crowe, A. and Booty, W. G. (1995). A multi-level assessment methodology for determining the potential for groundwater contamination by pesticides. Environmental Monitoring and Assessment, 35(3), 239-261. doi:10.1007/BF00547635.

[12] Day, R., Abrahams, P., Bateman, M., Beale, T., Clottey, V., Cock, M., Colmenarez, Y., Corniani, N.,Early, R., Godwin, J., Gomez, J., Moreno, P. G., Murphy, S. T., Oppong-Mensah, B., Phiri, N., Pratt, C., Silvestri, S. and Witt, A. 2017. Fall armyworm: impacts and implications for Africa. Outlooks on Pest Management 28 (5): 196201. DOI 10.1564/v28_oct_02.

[13] De Groote, H., Kimenju, S. C. Munyu, B., Palmas, S., MenaleKassie, M. and Bruce, A. 2020. Spread and impact of fall armyworm (Spodoptera frugiperda J.E. Smith) in maize production areas of Kenya. Agriculture, Ecosystems \& Environment, 292: (15) 106804. doi.org/10.1016/j.agee.2019.106804.

[14] Deshmukh, S., Kalleshwaraswamy, C. M., Maruthi, M.S. and Pavithra, H. B. 2018. Biology of invasive fall army worm Spodoptera frugiperda (J.E. Smith) (Lepidoptera: Noctuidae) on maize Indian Journal of Entomology, 80 (3): 540-543. DOI: 10.5958/0974-8172.2018.00238.9.

[15] Devi, S. 2018. Fall armyworm threatens food security in southern Africa Lancet, 391: 727.

[16] FAO 2017. Advisory Note on FAO Actions on Fall Armyworm (FAW) in Africa, Food and Agriculture Organization (FAO), Rome.

[17] FAO 2018. FAO, Tanzania sign agreement to respond to fall armyworm. Food and Agriculture Organization. http://www.fao.org/tanzania/news/detail-events/en/c/1104627/

[18] FAO 2018. Integrated management of the fall armyworm on maize. A Guide for Farmer Field Schools in Africa, Food and Agriculture Organization (FAO), Rome.

[19] FAO 2019. First Detection of Fall Armyworm in China. FAO; Rome, Italy: [(Accessed on 22 April 2020) Available online: https://www.ippc.int/fr/news/first-detection-of-fall-armyworm-inchina/

[20] FAO 2019. First Detection Report of the Fall Armyworm Spodoptera frugiperda (Lepidoptra: Noctuidae) on Maize in Myanmar. (Accessed on 22nd April 2020); Available online: https://www.ippc.int/en/countries/myanmar/pestreports/2019/01/first -detection-report-of-the-fall-armyworm-spodoptera-frugiperdalepidoptra-noctuidae-on-maize-in-myanma/

[21] Fotso Kuate, A., Hanna, R., Doumtsop Fotio, A. R. P., Abang, A. F, Nanga, S. N., Ngatat. S., Tindo, M., Masso, C., Ndemah, R., Suh, C., Kouma, K. and Fiaboe, M. 2019. Spodoptera frugiperda Smith (Lepidoptera: Noctuidae) in Cameroon: Case study on its distribution, damage, pesticide use, genetic differentiation and host plants. PLoS ONE 14 (4): e0215749. https://doi.org/10.1371/journal. pone.0215749.
[22] GAIN 2017. Fall Armyworm in Tanzania and East Africa. A report by Global Agriculture Information Network (GAIN), USDA foreign Agricultural Services. https://apps.fas.usda.gov/newgainapi/api/report/downloadreportbyfil ename?filename $=$ Fall $\% 20$ Armyworm $\% 20$ in $\% 20$ Tanzania $\% 20$ and $\%$ 20East\%20Africa Nairobi Tanzania\%20\%20United\%20Republic\%20of_6-28-2017.pdf

[23] Goergen G., Kumar P. L., Sankung S. B., Togola A. and Tamò M. 2016 First report of outbreaks of the fall armyworm Spodoptera frugiperda (JE Smith) (Lepidoptera, Noctuidae), a new alien invasive pest in West and Central Africa. PLoS ONE. 11:e0165632. doi: 10.1371/journal.pone.0165632.

[24] Hruska, A. 2019. Fall armyworm (Spodoptera frugiperda) management by smallholders. CAB Reviews, 14, No. 043, 1-11.

[25] https://video.search.yahoo.com/search/video? $\mathrm{p}=$ fall+army+worm+co ntrol+in+india+you+tube+using+sand+and+ash\#id=1\&vid=6518d41 210a41875581260134cec60e1\&action=click (Accessed: 13 March 2020).

[26] https://video.search.yahoo.com/search/video?p=fall+armyworm+con trol+in+india+youtube\#id=1\&vid=db22db61e 8 ba3eba912a46e48626 2567\&action=click (Accessed: 29 May 2020).

[27] https://www.sua.ac.tz/news/fall-armyworm-farmers-nightmare (Accessed: 26 June 2020).

[28] https://www.youtube.com/watch?v=9tOLYD7eJEA (Accessed: 28 March 2020).

[29] https://www.youtube.com/watch?v=JIFOZAj3iT8 (Accessed: 30 March 2020).

[30] https://www.youtube.com/watch?v=jR4p_AWuFZc (Accessed: 14 March 2020).

[31] https://www.youtube.com/watch?v=p05C1q2HRrg (Accessed: 18 June 2020).

[32] https://www.youtube.com/watch?v=ZCFuI2ja8Oo (Accessed: 10 June 2020).

[33] Huesing, J. E., Prasanna, B. M., McGrath, D., Chinwada, P., Jepson, P. and Capinera J. L. 2018. Integrated pest management of fall armyworm in Africa: an introduction. B.M. Prasanna, J.E. Huesing, R. Eddy, V.M. Peschke (Eds.), Fall Armyworm in Africa : a Guide for Integrated Pest Management, CIMMYT, USAID, México (2018), pp. 1-9.

[34] Igyuve, M., Ojo, G., Ochigbo, A. E. and Ugbaa, M. (2018) Fall army worm (Spodoptera frugiperda); it's biology, impact and control on maize production in Nigeria.

[35] Sharanabasappa D; Kalleshwaraswamy, C. M.; Asokan, R.; Mahadeva Swamy, H. M.; Maruthi, M. S.; Pavithra, H. B.; Hegde, K.; Navi, S.; Prabhu, S. T.; Goergen, G. 2018. First report of the Fall armyworm, Spodoptera frugiperda (J E Smith) (Lepidoptera: Noctuidae), an alien invasive pest on maize in India. Pest Management in Horticultural Ecosystems, v. 24, n. 1, p. 23-29

[36] Macauley, H. 2015. Cereal crops: rice, maize, millet, sorghum, wheat. Background paper. feeding Africa: an action plan for African agricultural transformation. https://www.afdb.org/fileadmin/uploads/afdb/Documents/Events/Da kAgri2015/Cereal_Crops_Rice_Maize___Millet_Sorghum_Wheat.pdf Dakar: Senegal.

[37] Prasanna, B. M., Huesing, J. E., Eddy, R., Peschke V. M. (edds) 2018. Fall Armyworm in Africa : a Guide for Integrated Pest Management. CIMMYT, USAID, México (2018). 


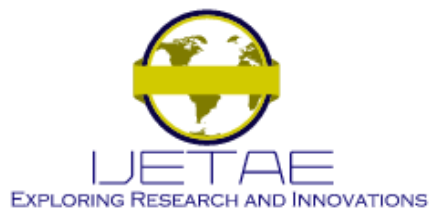

International Journal of Emerging Technology and Advanced Engineering Website: www.ijetae.com (ISSN 2250-2459, ISO 9001:2008 Certified Journal, Volume 10, Issue 11, November 2020)

[38] Qiu-Lin, W., Li-Mei, H., Xiu-Jing S., Yu-Ying. J., Jie L., Gao H. and Kong-Ming W. 2019. Estimation of the Potential Infestation Area of Newly-invaded Fall Armyworm Spodoptera frugiperda in the Yangtze River Valley of China. Insects, 10(9): 298. doi: 10.3390/insects 10090298
[39] Rose, A. H., Silversides, R. H. and Lindquist O. H. 2012. Migration flight by an Aphid, Rhopalosiphum maidis (Hemiptera: aphididae), and a noctuid, Spodoptera frugiperda (Lepidoptera: noctuidae) Canadian Entomologist, 107: pp. 567-576.

[40] Stokstad, E. and 2017. New crop pest takes Africa at lightning speed. Science. 356:473-474. Doi: 10.1126/science.356.6337.473. 